\title{
Review: One of Important Metabolic Disorder is Sara Correlation between Milk Fat Depression
}

\author{
o Sizmaz* \\ Department of Animal Nutrition and Nutritional diseases, University of Ankara, Turkey
}

Submission: March 03, 2018; Published: May 16, 2018

*Corresponding author: O Sizmaz, Department of Animal Nutrition and Nutritional diseases, Faculty of Veterinary Medicine, University of Ankara, Turkey, Tel: 905335684851; Email: ozgeabacioglu@gmail.com

\begin{abstract}
Rumen acidosis is a digestive disorder that occurs when ruminants consume carbohydrate-based feeds that can be fermented easily. Under normal conditions, the $\mathrm{pH}$ value of the rumen is between 5.5 and 7.0, while the critical value for acidosis is 5.8. Acidosis categorized in different forms is known as acute and subacute (SARA) or more frequently clinical and subclinical acidosis. Acute acidosis occurs whenthe $\mathrm{pH}$ value of therumenfallsbelow 5.0, SARA, which occurs on a flock basis and results in severe economic losses, occurs when the pH value is between 5.0 and 5.5. Many studies have shown that the cause and theconsequences of thedecrease in $\mathrm{pH}$ value lead to acidosis. The accumulation of volatile fattyacids (VFA), which is abolished by the degradation of carbohydrates, decreases the $\mathrm{pH}$ value of the rumen accumulation and decreases the $\mathrm{pH}$ value, thus reducing the feed consumption.
\end{abstract}

Keywords: Acidosis; Ruminant; SCFA; pH value; Fattyacids; Carbohydrates; Acidosis; Feed stuffs; Bovine disease; Acetic acid; Butyric acid; Propionic acid; Endotoxins; Lypolysis; Insulin; Diagnosing; Grains

\section{Ruminal Acidosis}

Ruminal acidosis is a bovine disease that affects ruminants that are fed with high-grain diets. Easily fermentable carbohydrates inclusion creates short-chain fatty acids (SCFA) within a short time after consumption, which can cause a reduction in ruminal $\mathrm{pH}$ [1]. It can be present in different forms, is known as acute and subacute or more frequently clinical and subclinical acidosis. Factors affecting of acidosis are not only high grain diets, but also type of ration meaning of the ratio of for age and concentrate, the source of grains, processing methods of feed stuffs, moisture of feed, feding system, feding with different diets without adaptaion period and sometimes my cotoxins and unsaturated fatty acids.

According to results of some studies the prevalence of SARA in dairy herds is atrange between $11 \%$ and $26 \%[2,3]$, although on account of no clinical signals, this prevalence might be even higher.

\section{Signals of SARA}

Since SARA has a non-clinical symptom, the points to note that is important for farmers and nutritionists are summarized below.

Due to the SCFA accumulation, the ruminal pH drops. This parameter also crucial for acidosis however the essential point is not only reduction of $\mathrm{pH}$ but also the number of hours of reduction, because the fluctuations that occur during the day due to feeding estion are ordinary. Because of the high production of SCFA resulted in lower ruminal motility that can be caused dry matterin take reduction, since the bacterial endotoxins release and the osmolority of rumen increase as well [4].

The SARA also alters the faeces particle size that may be enlarged around $1-2 \mathrm{~cm}$ or including undigestible grains and consistency that can be described as bright yello wish with foamy appearing and a sweets our smell [5]. Additionally, SARA can be caused the depression of milk fat due to the high grainpoor forage diets because of the acetic acid comes from forages.

\section{Milk Fat Depression}

Inruminants, milk fat is produced by de novo synthesis with aceticacid and B-hydroxybutyric acid. Lower forage: concentrate ratio in diets reduces the concentration of acetic acid and therefore the amount of milk fat. On the other hand, Higher concentate diets increase the propionic acid concentration which has anticetogenic effect that decrease the usage of B-hydroxy butyric acid. Additionally while propionic acid increase, Vitamin $\mathrm{B}_{12}$ production levels decrease. This leads to a reduce in milk fat synthesis from acetic acid in udder. The last correlation between SARA nad the milk fat depression is that high concentrate and 
limited forage increase relative glucose and then insulin activity which causes a decrease in plasmatrigly cerides due to lypolysis [6].

\section{Conclusion}

Taken together, it is possible to prevent the negative effects of SARA which causes significant economic loss especially milk fat depression, through managements and feding strategies. Firslty, farmers and nutritionists should be a good observer by monitoring the cows and take precautions in the correct way. Because the signals of SARA is crucial for diagnosing this metabolic disorder.

\section{References}

1. Aschenbach JR, Penner GB, Stumpff F, Gäbel G (2011) Ruminant nutrition symposium: Role of fermentation acid absorption in theregulationof ruminalpH. Journal of Animal Science 89: 1092-1107.
2. Garrett EF, Nordlund KV, Goodger WJ, Oetzel GR (1997) Across-se ctionalfieldstudyinvestigatingtheeffect of periparturient dietary management on ruminal $\mathrm{pH}$ in early lactation dairy cows. Journal of Dairy Science 80: 169.

3. Kleen JL, Hooijer GA, Rehage J, Noordhuizen JPTM (2009) Subacute ruminal acidosis in Dutch dairyherds. Veterinary Record 164: 681-684.

4. Kleen J, Hooijer G, Rehage J, Noordhuizen J (2003) Subacute ruminal acidosis (SARA): A review. Journal of Veterinary Medicine A 50: 406414.

5. Hall MB (2002) Characteristics of manure: What do theymean? InProceedings of theTri-StateDairy Nutrition Conference. Fort Wayne, Indiana, USA, pp. 141-147.

6. Humer E, Aschenbach JR, Neubauer V, Kröger I, Khiaosa-ard R, et al (2017) Signals for identifying cows at risk of subacute ruminal acidosis in dairy veterinary practice. Anim Physiol a Anim Nutr 102(2): 380392.

\section{Your next submission with Juniper Publishers will reach you the below assets}

- Quality Editorial service

- Swift Peer Review

- Reprints availability

- E-prints Service

- Manuscript Podcast for convenient understanding

- Global attainment for your research

- Manuscript accessibility in different formats ( Pdf, E-pub, Full Text, Audio)

- Unceasing customer service

Track the below URL for one-step submission https://juniperpublishers.com/online-submission.php 